\title{
THE SPIRITUAL GAP THE UNKNOWN ZMEY GORIANIN FILLS IN THE PUBLIC DEVELOPMENT OF BULGARIA
}

\author{
Venelin Terziev ${ }^{1}$ and Silva Vasileva ${ }^{2}$ \\ ${ }^{1}$ Full Member of the Russian Academy of Natural History, Professor, Eng., D.Sc. (National \\ Security), D.Sc. (Economics), D.Sc. (Social Activities), Ph.D. Russian Academy of Natural History, \\ Moscow, Russia; Georgi Rakovski Military Academy, Sofia, Bulgaria; University of Rousse, \\ Rousse, Bulgaria; Kaneff University Hospital, Rousse, Bulgaria, vkterziev@gmail.com \\ ${ }^{2}$ Regional Library „Lyuben Karavelov”, Rousse, Bulgaria, deputy@libruse.bg
}

\begin{abstract}
This work is dedicated to the $115^{\text {th }}$ anniversary of the birth of Svetlozar Akendiev Dimitrov - 'Zmey Goryanin' and aims at answering questions about his influence on the Bulgarian spirituality, literature and society. The author made an attempt for a brief overview and analysis of Zmey Goryanin`s research and creative activity, simultaneously trying to explain his influence on the social processes taking place at that time.
\end{abstract}

Keywords: influence on the Bulgarian spirituality, literature and society, research and creative activity.

\section{INTRODUCTION}

Various and diverse events, personalities and facts help give meaning and enrich the spiritual concept "library". Over the years, its priorities have changed many times. But indisputably and for sure what makes it different from all other spiritual cultural centers are its collections. Part of this peculiarity, which creates the appearance of every public library, including the "Lyuben Karavelov" Regional Library in Rousse, are the preserved archives and original documents related to researchers and artists who were born and worked in Ruse.

\section{THE SPIRITUAL GAP THE UNKNOWN ZMEY GORIANIN FILLS IN THE PUBLIC DEVELOPMENT OF BULGARIA}

The collection of literature related to local history includes various resources - books, periodicals, manuscripts, prints, excerpts, personal documents, memoirs, maps, files and more. Due to the variety of materials and the fact that most of these documents and objects are difficult to find, storing them is a challenging and responsible task. It is an opportunity to preserve the local history of the area, while their study and research helps to restore names, facts and events. These collections are also highly important due to the fact that sometimes they contain the only originals, very often in the form of unofficial documents (manuscripts, excerpts, preprints, etc.), necessary for research.

The role of the Local History Department at the Rousse Regional Library is similar. Along with the general literature about Ruse and the region, which serves the representatives of the local community, the department keeps part of the personal archive of Zmey Goryanin, the banned and forgotten writer of the 1940 s and 1950s. The study of the documents makes it possible to restore the full authorial presence of the writer during a period when publication of his works was not allowed. 
Those interested in literature and the history of literature for the first time encounter the name, or more precisely, the pen name "Zmey Goryanin", most often as students. And - typically for a student - they forget about him after the next exam. The memory of a writer with a strange pen name remains, but the lack of access to the books themselves is a natural way for him to gradually fade. And if today the fading of this name is a negative sign only for those who do not know the author and his work, then the writer himself had experienced and suffered it in the first person.

Born in 1905 in Rousse, Svetlozar Akendiev Dimitrov (as his real name is) had a fate full of ups and downs. "Poor son of an accountant - a narrow socialist and "unbridled bohemian", scattered childhood in Ruse, Svishtov, Plovdiv and Rousse again" - this is how the beginning of his life is described by Assoc. Prof. Atanas Kolev - one of his most zealous researchers and advocate for the rehabilitation of the writer (Kolev, 2018). Zmey Goryanin published his first poem in 1921, when he was only 16 years old. Two years later he met Prof. Alexander Balabanov, thanks to whom he joined the elite literary circle "Razvigor". Ten years later was his first meeting with Elin Pelin and their collaboration grew into a friendship that lasted until his last days.

From his youth he had to work to support himself, but this did not change his desire to be a writer. And he succeeded. Until 1944, his name was associated with 79 editions, of which 14 books, 10 textbooks and 55 brochures, signed with many and varied pen names. But the one that makes him recognizable among Bulgarian readers is undoubtedly the Zmey Goryanin. There are various assumptions about the origin and meaning of the pen name. Whatever the truth - it is the subject of research by literary critics. Noteworthy, for the first time the image of the "Zmey" in the works of Svetlozar Dimitrov appeared in 1930 in the miniature eight-page brochure "Dobrudzha Songs" published by the Ruse youth Dobrudzha organization "Stefan Karadzha", where on the back of the publication there was an engraving of Dragon pierced with a sword. Two years later the Literary Voice newspaper issues a document certifying that "Svetlozar Dimitrov - Zmey Goryanin - is a regular contributor to the newspaper", which established the earliest use of the writer's legendary pen name (Kolev, 2018).

In the autumn of 1930, Zmey Goryanin and his wife moved to Sofia, where, after a long search for a job, Svetlozar Dimitrov joined a clerk in various departments. The 1930s were extremely productive for the writer. His collection of short stories "The Last Day" was published, which is dedicated to the old Ruschuk, and the foreword is by another prominent Ruse resident - Acad. Michail Arnaudov. The novel "Prince Ivan Kulin", the historical novel "Bacho Kiro", the trilogy "The Danube Flows" - "Lights and Shadows" (1938), "The Power of Slaves" (1939) and "Thirst Satisfied" (1940) were printed. He created wonderful Christian lyrics and children's literature, collaborated with and published in the Bulgarian periodicals. His works were published in the magazines "Hyperion", "Styag", "Bulgarian Thought", "Stara Planina", as well as in the newspapers "Svetlostruy", "Literary Voice" and others. In co-authorship with the teacher Ivan Georgiev he wrote textbooks in history and homeland studies. In 1940 Svetlozar Akendiev Dimitrov - Zmey Goryanin received an award of the Writers Union of Bulgaria (Trifonova, 2007). A year later he received an award of the Association of Writers and Historians for his novel "The Power of Slaves", and in 1942 the Bulgarian Academy of Sciences awarded him a prize of BGN 8,000 for the novel "Zvezda Kervandzhiyka".

In 1941-1943 he was mobilized three times as a military correspondent and lecturer writer and was sent to Macedonia and Western Thrace. His mobilization as a military lecturer and writer in Serbia worsened his health. The year 1942 turned out to be fateful for him, when he briefly became a censor in the Office of Censorship. This was the reason why in October 1944 his books were included in the List of Fascist Literature and were confiscated from libraries, and he himself was arrested and tried by the People's Court. In the same court trial, many other prominent activists were sentenced: Fani Popova-Mutafova, Dimitar Talev, Danail Krapchev, Yordan Stubel, Prof. Stefan Konsulov, Rayko Alexiev and others. At the same time, another prominent Rousse resident, Acad. Michail Arnaudov, was in prison. In his prison notes Zmey Goryanin himself described their condition with a touch of irony: "On the bright side, the company here is excellent: all leaders - aces of our political, social, cultural and economic life". He was sentenced to one year in prison for his short censorship in the Office of Censorship. Although he was released early, his famous pen name was excommunicated and his name was completely erased from the publishing plans.

With a protocol of November 1944, the Board of Directors of the Writers Union of Bulgaria expelled 29 writers, including Zmey Goryanin, on the grounds that "their activities contradicted the interests of our people and culture" (Prokopieva, 2015). Regarding the accusations, Goryanin himself made an interesting tragicomic comment in his unfinished manuscript "The Incarnations of Ventseslav Galushkin", included in Tsveta Trifonova's book: "...we are not a fascist and pro-German, we have no medals, we have not participated in legations, we have not sent a New Year's greeting telegram to Hitler, we've seen Beckerle only at parades...We are not this or that, our only fault is that we are Bulgarian, one fighting for unification, idealist, fanatic, dreamer, with false beliefs and national ideals in general - a significant guilt we did not know 
we will have to pay for" (Trifonova, 2007). Prosecutors used as an argument to arrest and detain Zmey Goryanin for his great Bulgarian chauvinism, based on his work and the writer's interest in Bulgarian history. The accusations were ridiculous, but also completely enough for him to spend 10 months in the central Sofia prison.

Henceforth, the life of the writer became a constant ordeal. The blows of fate he endured come from all sides. His publications, as I have already mentioned, were banned. In his research on the presence of Zmey Goryanin in the protocols for destroyed books in the 1940s, Assoc. Prof. Dr. Ilko Penelov studied the fate of the author's banned works and found out that 19 titles, which was almost $28 \%$ of the writer's published books, were officially prohibited and intended to be erased from library collections, publishing houses, bookstores, warehouses, etc. places where they would be found (Penelov, 2015). And although he was pardoned, his famous pen name was excommunicated and the author was banned. Thus, the "people's power" deprives him of the right to do what he aspired to as a child.

But even in a situation like this, we can see the strong spirit of this, unfortunately, so little known writer today. After his release from prison, his "ideological mentors" Georgi Karaslavov, Hristo Radevski and Mladen Isaev suggested that he should repent publicly and sign a declaration that he meant no harm while working as a censor. The author flatly refused explaining that it was not necessary to declare something that was a fact. And of course, he paid for it, literally. For the next decade, Zmey Goryanin's name was not mentioned publicly, his works were not published, and he had to sell stamps in a small wooden booth to take care of his family. He survived thanks to his friends, some of whom he met during his time in prison.

Zmey Goryanin continued to write even in prison. "SOFCENZAT" Publishing House is the only one that "published" his "Sketches and Notes" - a small prison notebook where the writer wrote down epigrams and memories of his cellmates. In fact, these were self-published manuscripts and typewritten pages that the author had designed himself as books or collected at home. "SOFCENZAT" is an ironic allusion to the typical and widespread during the years of socialism abbreviation of organizations and institutions, in this case Sofia Central Prison. 5 of these unique editions are kept in the Local History Department of the 'Lyuben Karavelov' Regional Library - Rousse. Four of them, "Ephraim the Barefoot", "Ghost”, "Insomniacs" and "One Life", are manuscripts, and "The Blue Hour" is a story preserved in eight typewritten pages. The publications came to the library through a donation made in the late 80 s of the $20^{\text {th }}$ century by Svetlozar Dimitrov's wife Sonya.

Manuscripts were made in the form of a book with dimensions: $16 \times 17$ and $19 \times 17 \mathrm{~cm}$. Written in the author's fine calligraphic handwriting, the "books" were bound and made to look like real editions. Two of them - "Ghost" and "One Life" were dedicated to Dr. Todor Valchev and Dr. Zahari Zahariev, respectively. The lower right corner of the "Ghost" cover page, right where the messages of the other two books were written, was cut out, and whether it was dedicated to someone or there was other text, remains a mystery. On the title page of "Ephraim the Barefoot" there was a sheet of quotation from the Gospels of Matthew, Mark, and Luke. At the end of each book, the author documented their writing in the Sofia Central Prison, where he was a political prisoner.

Of the works written in prison and those kept in the Rousse library, "The Blue Hour" is signed with one of the many, but not so popular pen names of Svetlozar Dimitrov - Ivo Skrebar.

After his release from prison at the end of 1945, Zmey Goryanin was banned from publishing. But despite the "veto" on his publications, the writer did not stop creating and making his own books that were never meant to be published. He wrote thousands of epigrams, the already mentioned memoir "Sketches and notes" wrote in prison, the autobiographical notes "The Red Hotel", the manuscript "My Friend Elin Pelin", the unfinished satirical story "The Incarnations of Ventseslav Galushkin". The self-made collection of short stories "Bread from Heaven" (1954), the collections of poems "Poem for Life and Death" (1952), Loneliness. Unnecessary Poetry (1953), Night and Day (1955) were published. Together with the 50 historical books from before September 9, 1944, the hundreds of poems handwritten and bound in self-published notebooks, drafts, drawings and sketches, these works are a priceless heritage of Zmey Goryanin for the Bulgarian culture.

The library also keeps a copy of the self-published poetry collection "Night and Day", which contains his poetic works for the period 1945-1955. The poetry collection contains three cycles of poems: "Night and Day", "Unnecessary lyrics" and "Military lyrics". Each of the sections has its title page and an additional sheet, identical in content, but different in color and size from that of the collection of poems.

On the first page there is a handwritten dedication by the author, which goes: "To the wonderful man, a rare friend and unjustifiably generous connoisseur of my poems Todor Bikov, to whom I gladly and lovingly give this manuscript. Ruse, 10/02/1955, Zmey Goryanin". Under the signature there is a number 62 - the 
sequence of the edition, which the author made himself. The typewritten pages are carefully bound and sewn by hand, and the cover is also hand-made with ink and pen. The copy was donated to the library by Todor Bikov's son - Vladimir, and his handwritten letter has been preserved as well.

The author, who was also a gifted artist, illustrated his books with his drawings, bound them and in most cases gave them as presents to his friends. But that was not enough for him. Zmey Goryanin longed for real contact with the audience, for his works to be published and read officially. During the last 10 years of his life Svetlozar Dimitrov published Christian lyrics under various pen names in the publications of the Bulgarian Orthodox Church - "Church Gazette" and "Spiritual Culture" magazine. From this period, original drawings in ink and colored pencils have been preserved and stored in the Local History Department of the "Lyuben Karavelov" Regional Library. Carefully preserved so far, the works are to be digitized and included in an electronic bibliography, which will be developed by the library and implemented with the support of the National Fund "Culture".

The stay in prison, the repressive actions that followed, including the "interception" of personal correspondence, the search of his home, as well as the inability to publish and be with his readers, seriously shook the health of Svetlozar Dimitrov. He died in August 1958 in the monastery of the "Seven Thrones" at the age of 53. The monastery, located near the village of Osenovlak, where Zmey Goryanin found peace for years, became the last home of the banned writer.

After his death, his wife, Sonya Dimitrova, started a mission to find and preserve everything created by Zmey Goryanin. Thanks to her, part of the writer's archive is kept in the Ruse cultural institution today. The library also keeps letters exchanged between Sonya Dimitrova and the teacher and a long-time friend of Zmey Todor Dashkov. From their correspondence it is clear that the only consolation of Sonya Dimitrova was "the republishing of his books, which are still in great demand today", as well as her satisfaction that it is his former teacher who would perform this important mission. In his response, Dashkov believes that in the initiative to "celebrate Ruse writers born in Ruse or who worked in Rousse... Svetlozar cannot be ignored".

Unfortunately, it would take more than a decade for his books to be printed. This happened only in 1976, when on the occasion of the 100th anniversary of the April Uprising, 6 of his works were republished. Another long and forced oblivion followed, which lasted until 1992. On the occasion of the anniversary of the uprising, Zmey Goryanin was proposed for rehabilitation as an author who in his works recreated the struggle for national liberation, but the proposal was rejected.

Another letter from Sonya Dimitrova, this time to a librarian from the Ruse library, points out the way to receive the documents and works. At the end of 1989 (the date of the letter is December 29, 1989), a letter was received in the library from Zmey Goryanin's wife - Sonya Dimitrova and Nevyana Buyukliyska, his niece, in which they confirmed that they had chosen from the large and diverse collection of the writer, new documents, which are described in the donation book: "Donation of folders, 2 pcs. with manuscripts and typewritten works of Zmey Goryanin. Pictures of Zmey Goryanin - 1 pc. and 1 photo of his wife Sonya Dimitrova". The donation was received in 1990.

\section{CONCLUSION}

Today, the collection of the writer preserved in the library is a separate fund of over 450 original documents that reveal the cultural and historical reality of our country from the first half of the 20th century. With a clear awareness that this wealth obliges, and its preservation is our responsibility for future generations, the library team has developed a project whose idea is to promote and present in an accessible way our literary heritage, which will raise the awareness about the contribution of Zmey Goryanin in the formation of the Bulgarian national identity from the middle of the last century. Its aim is to facilitate the access of researchers and amateurs to the writer's work with the help of modern technologies and to restore the name of an artist who does not hesitate to state before the people's court: "None of my actions has ever been treacherous, mean and anti-national or provoked by greed and selfishness... judge me as a prodigal son, but as a true son of Bulgaria and the Bulgarian people".

Zmey Goryanin's life was a series of challenges he had passed. This requires inner strength, courage and self-control. And he deserves to be known and remembered.

\section{REFERENCE LIST}

Kolev, A. (2018). Zmey Goryanin Chronicle. Life and creativity (1905 - 1598 - 2017). Rousse: Avant-garde 
print.

National scientific conference on the occasion of 110 years after the birth of the writer Svetlozar Akendiev Dimitrov. (2015). Zmey Goryanin - The Stranger. (S. Vasileva, Ed.) Ruse: Lyuben Karavelov Regional Library

Penelov, I. (2015). Unknown under duress - Zmey Goryanin in the protocols for destroyed books in the 40s. National Scientific Conference on the Occasion of 110 years after the birth of the writer Svetlozar Akendiev Dimitrov (pp. 73 - 81). Ruse: Lyuben Karavelov Regional Library.

Prokopieva, T. (2015). The trial against the writer Zmey Goryanin (March - April 1945). National Scientific Conference on the Occasion of 110 years after the birth of the writer Svetlozar Akendiev Dimitrov (pp. 35 - 48). Ruse: Lyuben Karavelov Regional Library.

Trifonova, Ts. (2007). The life of Zmey. - Writers and the profile. Political and literary essays and documents. (2nd ed.). Veliko Tarnovo: Faber. 